\title{
Phenolic compound and antioxidant activity of two slightly consumed wild mushrooms (Lentinus squarrosulus and Auricularia politrich) in three regions from center Ivory Coast
}

\author{
Hermann Fourier Atta Anno 1,a, Hyacinthe Attoh Anon ${ }^{2, b, *}$, Koffi Amoin Gisèle, \\ Appolinaire Kouamé Kouassi ${ }^{3, d}$, Jean Parfait Eugène Kouadio ${ }^{1, e}$ \\ ${ }^{1}$ Laboratoire de Biocatalyse et des Bioprocédés, Université Nangui Abrogoua, Abidjan, Côte d'Ivoire, 02 BP 801 Abidjan 02, Côte \\ d'Ivoire \\ ${ }^{2}$ Laboratoire de Biochimie, Microbiologie et de Valorisation des Agro-Ressources (LBMVA), Institut de Gestion Agropastorale, Université \\ Peleforo Gon Coulibaly, Korhogo, BP 1328 Korhogo, Côte d'Ivoire \\ ${ }^{3}$ Laboratoire de Biochimie- Génétique, Université Peleforo Gon Coulibaly, Korhogo, BP 1328, Korhogo, Côte d'Ivoire \\ ${ }^{*}$ Corresponding author

\section{A R T I C L E I N F O A B S T R A C T} \\ Research Article \\ Mushrooms contain a variety of secondary metabolites, including various phenolic compounds, \\ which have been shown to act as excellent antioxidants. In this study, the contents of total phenolic, \\ flavonoids and tannins of mushrooms methanolic extracts were evaluated by colorimetric assays to \\ ranges of $277.36 \pm 0.66$ to $420.86 \pm 0.90 \mathrm{mg}$ (GAE)/100g DW; $31.99 \pm 0.90$ to $90.90 \pm 0.07 \mathrm{mg}$ \\ Received : 17/05/2021 \\ Accepted : 13/06/2021 \\ (QE)/100g DW and $150.61 \pm 0.16$ to $220.47 \pm 1.01 \mathrm{mg}$ (TAE)/100g DW respectively. HPLC-profiles \\ of methanolic extracts indicated that the individual phenolic compounds found to the samples of \\ the species of mushrooms that are Lentinus squarrosulus and Auricularia politrich revealed us that \\ gallic acid, catechin, acid $\rho$-hydroxybenzoïc, acid ellagique and naringerin were presented to the \\ level of the two species. With respect to organic acids, the results showed that citric acid and fumaric \\ Keywords: \\ Antioxidant activity \\ Saprophitic mushrooms \\ Phenolic compounds \\ acid was the major organic acid in all the samples of both mushrooms species. The methanolic \\ extracts of the two mushrooms exhibited the high DPPH radical scavenging activities ranging from \\ $34.10 \pm 1.12$ to $58.95 \pm 0.52 \%$. These data indicated that these mushrooms could constitute a potential \\ good source of natural antioxidant for the local population.
} Côte d'Ivoire Auricularia politrich

\section{Introduction}

Fungi, constituting the most diverse and abundant group on the planet, are an excellent candidate for the production of bioactive metabolites due to their resemblance to the animal system (Vieira Gomes et al., 2019). Like plants, certain fungi are appearing favorably in the emerging industry, which represents non-wood forest products (Wills and Lipsey, 1999; Vieira Gomes et al., 2019). Once considered a food of low nutritional value, mushrooms are of particular interest today. Indeed, research on wild edible fungi of nutritional and medicinal interest has developed significantly in recent years and is now oriented towards the discovery of new sources beneficial to human health and having therapeutic effects on certain infectious diseases (Erbiai et al., 2021). Now, more than $80 \%$ of people consider them a "healthy" food and do not hesitate to include them in a diet aimed at good cardiovascular health (Stanton, 2006; Yuwa-Amornpitak et al., 2020). In recent decades, interest in fungi has jumped considerably due to their richness in phenolic compounds, tocopherols and carotenoids, considered to be the most responsible for antioxidant activity. In addition to antioxidant capacity, this diversity of biomolecular compounds in wild edible fungi is also responsible for other biological activities; namely, antibacterial, antifungal, anti-inflammatory, antitumor and antiviral properties (Aprotosoaie et al., 2017; Liaotrakoon and 
Liaotrakoon, 2018). These compounds can be involved in the protection against various diseases, due to their antioxidant potential (Silva et al., 2004). Polyphenols are very good anti mutagens and anti carcinogens with respect to one of their properties which is to be a very good powerful antioxidant (Middleton et al., 2000; Yuwa Amornpitak et al., 2020). Thus, anti-cancer drugs, cholesterol-lowering drugs, immunostimulants and antioxidants give fungi several therapeutic properties (Mizuno et al., 1995; Ferreira et al., 2007). In Côte d'Ivoire, several species of fungi have been identified (Avit et al., 1999). Among these are species like Lentinus squarrosulus and Auricularia politrich which are edible wild saprophytic fungi, which grow on decaying organic matter and perform different ecological functions. In this study, we were therefore interested in determining the phytochemical parameters and in evaluating the antioxidant activity of two edible saprophitic fungi in three regions of central Côte d'Ivoire identified as Lentinus squarrosulus and Auricularia politrich. In addition, we will study their individual organic acid.

\section{Materials and Methods}

\section{Sample Collection}

The harvest of the mushrooms has been made to the hand and only the aerial part has been harvested. In every locality (Gbeke, Belier, and N'Zi regions), a quantity (800 g; 2 times) of cool mushrooms has been harvested then conditioned in aired baskets. After picking, the samples of mushroom were immediately transferred to the laboratory for ulterior analysis. Taxonomic identification was achieved by Dr Souleymane Yorou Nourou (Abomé Calavy University of Benin/ Munich University of Germany), as Lentinus squarrosulus and Auricularia politrich.

\section{Extraction of Phenolic compounds}

The mushrooms have been dried to $25^{\circ} \mathrm{C}$ for ten days, until constant weight, as described previously with slight modifications (Ribeiro et al., 2007). Then, every sample of the mushroom has been ground in a fine-dried (cast IKA, Germany / Deutschland) powder. A sample (10 g) of every powder of the mushroom fine-dried has been extracted while moving with $50 \mathrm{~mL}$ of methanol $80 \%(\mathrm{v} / \mathrm{v})$ to $25^{\circ} \mathrm{C}$ for 24 hours. The residue was then extracted with two additional $50 \mathrm{~mL}$ portions of methanol. The combined methanolic extracts were evaporated at $35^{\circ} \mathrm{C}$ (rotary evaporator HEILDOLPH Laborata 4003 Control, Schwabach, Germany) until $25 \mathrm{~mL}$, prior to phenolic compound contents determination and HPLC analysis.

\section{Preparation of Organic Acid Extract}

The organic acids of dried mushroom samples were extracted by grinding (Waring Blendor, Polychimie, Abidjan, Côte d'Ivoire) in distilled water (1:10, w/v) and clarified by centrifuging at $4000 \mathrm{rpm}$ for 30 minutes. The supernatant was first filtered through Whatman no 4 paper, then through $0.45 \mu \mathrm{m}$ filter (Millipore; Sartorius AG, Goettingen, Germany) until $25 \mathrm{ml}$, prior to phenolic compound contents determination and HPLC analysis.
Determination of Total Phenolic Compounds Content

Contents of total phenolic compounds were estimated according Folin-Ciocalteu method (Singleton et al., 1999), A volume of $1 \mathrm{~mL}$ of methanolic extract of each sample was added to $1 \mathrm{~mL}$ of Folin-Ciocalteu's solution in a test tube. After 3 minutes, $1 \mathrm{ml}$ of $20 \%$ sodium carbonate solution was added to the mixture and adjusted to $10 \mathrm{~mL}$ with distilled water. The mixture was allowed to stand at room temperature in a dark environment for $30 \mathrm{~min}$. Absorbance was measured against the blank reagent at 725 $\mathrm{nm}$. Gallic acid was used for the calibration curve with a concentration range of $50-1000 \mu \mathrm{g} / \mathrm{ml}$. Results were expressed as mg gallic acid equivalent (GAE)/100g DW. All experiments were performed in triplicate.

\section{Determination of flavonoid content}

Total flavonoids content was determined as described previously with slight modifications (Meda et al., 2005). A volume of $0.5 \mathrm{~mL}$ of methanolic extract of each mushroom sample was diluted in $0.5 \mathrm{~mL}$ of distilled water. Then, 0.5 $\mathrm{mL}$ of aluminum chloride $10 \%(\mathrm{w} / \mathrm{v})$ and the same volume of sodium acetate $1 \mathrm{M}$ were added. Finally, $2 \mathrm{~mL}$ of distilled water was added and absorption reading at $415 \mathrm{~nm}$ was carried out after $30 \mathrm{~min}$ against a blank sample consisting of a $4 \mathrm{~mL}$ methanolic extract without aluminum chloride. Quercetin was used for the calibration curve with a concentration range of $0-100 \mu \mathrm{g} / \mathrm{mL}$. Results were expressed as mg of quercetin equivalent (QE)/100g DW. All experiments were performed in triplicate.

\section{Determination of Tannin Content}

The content of the tannins has been determined to use the method describes by Bainbridge et al. (1996). A volume of $1 \mathrm{~mL}$ of each methanolic extract was collected and mixed with $5 \mathrm{~mL}$ of reaction solution [vanillin $0.1 \mathrm{mg} / \mathrm{mL}$ in sulphuric acid $70 \%(\mathrm{v} / \mathrm{v})]$. The mixture was allowed to stand at room temperature in a dark environment for $20 \mathrm{~min}$. The absorbance was measured at $500 \mathrm{~nm}$ against a blank (without extract). Tannic acid was used for the calibration curve with a concentration range of $0-100 \mu \mathrm{g} / \mathrm{mL}$. The results were expressed as $\mathrm{mg}$ of tannic acid equivalents (TAE)/100g DW. All experiments were performed in triplicate.

\section{HPLC analysis of Phenolic Compounds}

The phenolic extracts prepared $(50 \mathrm{~mL})$ previously has been diluted in $100 \mathrm{~mL}$ of distilled water and $20 \mu \mathrm{L}$ of every sample has been analyzed to use an unit analytic HPLC equipped with a binary pump (LC-6A) (HPLC (Corporation Shimadzu, Japan) associated to a detector UV-LIVE (SPD-6A). Phenolic compounds were separated on a column ICSep ICE ORH-801 (length $25 \mathrm{~cm}$ ) at a temperature set at $30^{\circ} \mathrm{C}$. The mobile phase consisted of 50 $\mathrm{mM} \mathrm{NaH} \mathrm{H}_{2} \mathrm{PO}_{4}$ to $\mathrm{pH} 2.6$ (eluent $\mathrm{A}$ ), a solution of acetonitrile/ $\mathrm{NaH}_{4} \mathrm{H}_{2} \mathrm{PO}_{4}(80: 20, \mathrm{v} / \mathrm{v})$ (eluent B) and 200 $\mathrm{mM}$ acid $o$-phosphoric $\mathrm{pH} 1.5$ (eluent $\mathrm{C}$ ). The operating time was $70 \mathrm{~min}$ with a flow rate of $1 \mathrm{~mL} / \mathrm{min}$. Phenolic compounds in methanolic extract of mushroom samples were identified through comparison of their retention times and UV-visible spectra with those obtained by injection of the standard solution under the same conditions. Peak area was used for quantitation purposes, using external calibration with standards. 
Evaluation of Activity of the Antioxidant by DPPH Radical Scavenging

The antioxydant activity of every mushroom sample has been estimated by the method of trapping of the radical 1,1-diphenyl-2-picrylhydrazyle (DPPH.) according to the method described by Bidié et al. (2011). Thus, in every tube to test, 2,5 mL of every excerpt methanolic has been added to $1 \mathrm{~mL}$ of solution of DPPH. (1,1-diphenyl-2picrylhydrazyle, $3 \mathrm{mM}$ in the methanol). The tubes have been left to rest during $30 \mathrm{~min}$ to the obscurity and the reading of the absorbance has been done to the spectrophotometer to $517 \mathrm{~nm}$ against a white. Absorbance was converted to the DPPH radical-scavenging rate according to the equation:

$$
\operatorname{DPPH}(\%)=\left[\left(\mathrm{A}_{\text {control- }}-\mathrm{A}_{\text {sample }}\right) / \mathrm{A}_{\text {control }}\right] \times 100 \text {. }
$$

\section{Statistical Analysis}

All chemical analyses and assays were performed in triplicate, unless otherwise indicated. Results were expressed as mean values \pm standard deviation (SD). Analysis of variance (ANOVA) followed by Duncan's test was performed to test for differences between means by employing (statistica version 7.1) statistical software. Significance of differences was defined at the $5 \%$ level $(\mathrm{P}<0.05)$.

\section{Results and Discussion}

Contents of Phenolic Compounds, Flavonoids and Tannins

Table 1 show the content of total phenolic, flavonoids and tannins of methanolic extracts of Lentinus. squarrosulus and Auricularia. politrich collected in the three administrative regions of center from Côte d' Ivoire. Overall, for total phenolic, flavonoids and tannins contents, there were significant $(\mathrm{P}<0.05)$ differences between the two species in each region. The specie Auricularia polirtich possesses the most elevated contents of total phenolic (419.54 \pm 1.73 to $420.86 \pm 0.90 \mathrm{mg}(\mathrm{GAE}) / 100 \mathrm{~g}$ DW), total flavonoids $(88.31 \pm 1.73$ to $91.34 \pm 1.01 \mathrm{mg}$ $(\mathrm{QE}) / 100 \mathrm{~g} \mathrm{DW})$ and total tannins $(180.16 \pm 1.06$ to $220.47 \pm 1.01 \mathrm{mg}(\mathrm{TAE}) / 100 \mathrm{~g} \mathrm{DW})$ whatever is the region. But, the specie Lentinus squarrosulus possesses the weakest contents in these compounds. These relatively high contents of phenolic compound obtained in this work could be explained in part by the nature of the extraction solvent used. Also, depend the biotic conditions (species, body and the physiological stage) and abiotic (temperature, climat) (Ksouri et al., 2008). The contents in compounds total phenolic, total flavonoid and total tannin of the mushrooms of the Center from Côte d'Ivoire are comparable to data of the literature on edible wild mushrooms (Wong et al., 2013; Tibuhwa and Mwanga, 2014; Hussein et al., 2015; Tripathy et al., 2014). In addition, in the present study, the total phenolic and flavonoid contents were lower than recently reported values (Siangu et al. 2019).

\section{HPLC-profiles of Phenolic Compounds}

The analysis by HPLC of the methanolic extract of Lentinus squarrosulus samples and Auricularia politrich samples (Figure 1 and 2) showed the presence of four phenolic acids (gallic acid, protocatechiuc acid, ellagic acid, $\rho$-Hydroxybenzoic acid and $\rho$-coumaric acid), and two flavonoid (catechin and naringininn). Our results corroborate with those of Valentão et al. (2005); Ribeiro et al. (2007); Barros et al. (2009); Kouassi et al. (2016a; b) that mentioned the presence of the phenolic acid as the gallic acid, protocatechiuc acid, p-hydroxybenzoïc acid, cinnamic acid and of the flavonoïd as the catechin, quercetin in the excerpts of mushrooms. According to Ferreira et al. (2009), the phenolic acid constitutes the major part of the compound phenolic of the mushrooms.

One notes globally that the gallic acid and the $\rho$ hydroxybenzoïc acid are the most major with contents understood between $100.85 \pm 0.07$ and $105.70 \pm 6.50 \mathrm{mg} / \mathrm{kg}$ (DW) for the gallic acid and between 17.56 \pm 1.41 and $50.20 \pm 0.14 \mathrm{mg} / \mathrm{kg}$ (DW) for the $\rho$-hydroxybenzoïc acid. Otherwise, the ellagic acid is present in the mushrooms with weak contents around of $14.00 \pm 1.41 \mathrm{mg} / \mathrm{kg}$ (DW) (Table 2). The content in the $\rho$-hydroxybenzoïc acid is superior to those returned by Muszyńska et al. (2013) on six species of mushrooms of whose values are consisted between $1.28 \pm 0.20$ and $3.60 \pm 0.05 \mathrm{mg} / \mathrm{kg}$ (DW). The presence of the gallic acid, protocatechiuc acid, $\rho$ hydroxybenzoïc acid, and naringenin were also observed by many researchers (Bożena et al., 2013; Barros et al., 2009; Puttaraju et al., 2006).

\section{DPPH Radical Scavenging Abilities}

Overall in this study. methanolic extracts of mushroom samples had DPPH scavenging activity values around 50\% (Figure 3). Several species of edible wild mushrooms have also been tested with success for their activity of inhibition of the DPPH• (Mau et al., 2002; Ferreira et al., 2007; Obodai et al., 2014; Tibuhwa and Mwanga, 2014; Hussein et al., 2015).

Table 1. Total phenolic, flavonoids and tannins of two mushrooms from center of Côte d'Ivoire: Lentinus squarrosulus and Auricularia politrich

\begin{tabular}{l|lccc}
\hline \multicolumn{1}{c|}{ Especies } & \multicolumn{1}{c}{ Regions } & $\begin{array}{c}\text { Total phenolic } \\
(\mathrm{mg}(\mathrm{GAE}) / 100 \mathrm{~g})\end{array}$ & $\begin{array}{c}\text { Total flavonoid } \\
(\mathrm{mg}(\mathrm{QE}) / 100)\end{array}$ & $\begin{array}{c}\text { Total tannin }(\mathrm{mg} \\
(\mathrm{TAE}) / 100 \mathrm{~g})\end{array}$ \\
\hline \multirow{2}{*}{ Lentinus } & Gbêkê & $277.36 \pm 0.66^{\mathrm{a}}$ & $31.99 \pm 0.90^{\mathrm{a}}$ & $158.16 \pm 0.12^{\mathrm{b}}$ \\
squarrosulus & Bélier & $305.53 \pm 1.50^{\mathrm{b}}$ & $42.73 \pm 0.64^{\mathrm{b}}$ & $150.61 \pm 0.16^{\mathrm{a}}$ \\
& N'zi & $305.53 \pm 1.50^{\mathrm{b}}$ & $42.73 \pm 0.64^{\mathrm{b}}$ & $163.09 \pm 0.08^{\mathrm{c}}$ \\
\hline \multirow{3}{*}{ Auricularia politrich } & Gbêkê & $419.54 \pm 1,73^{\mathrm{a}}$ & $91.34 \pm 1,01^{\mathrm{b}}$ & $219.21 \pm 0.90^{\mathrm{b}}$ \\
& Bélier & $420.86 \pm 0,90^{\mathrm{a}}$ & $90.90 \pm 0,07^{\mathrm{b}}$ & $220.47 \pm 1.01^{\mathrm{b}}$ \\
& N'zi & $419.90 \pm 0,94^{\mathrm{a}}$ & $88.31 \pm 1,73^{\mathrm{a}}$ & $180.16 \pm 1.06^{\mathrm{a}}$ \\
\hline
\end{tabular}

Means not sharing a similar letter in a column are significantly different $\mathrm{P}<0.05$ as assessed by the test of Duncan. 

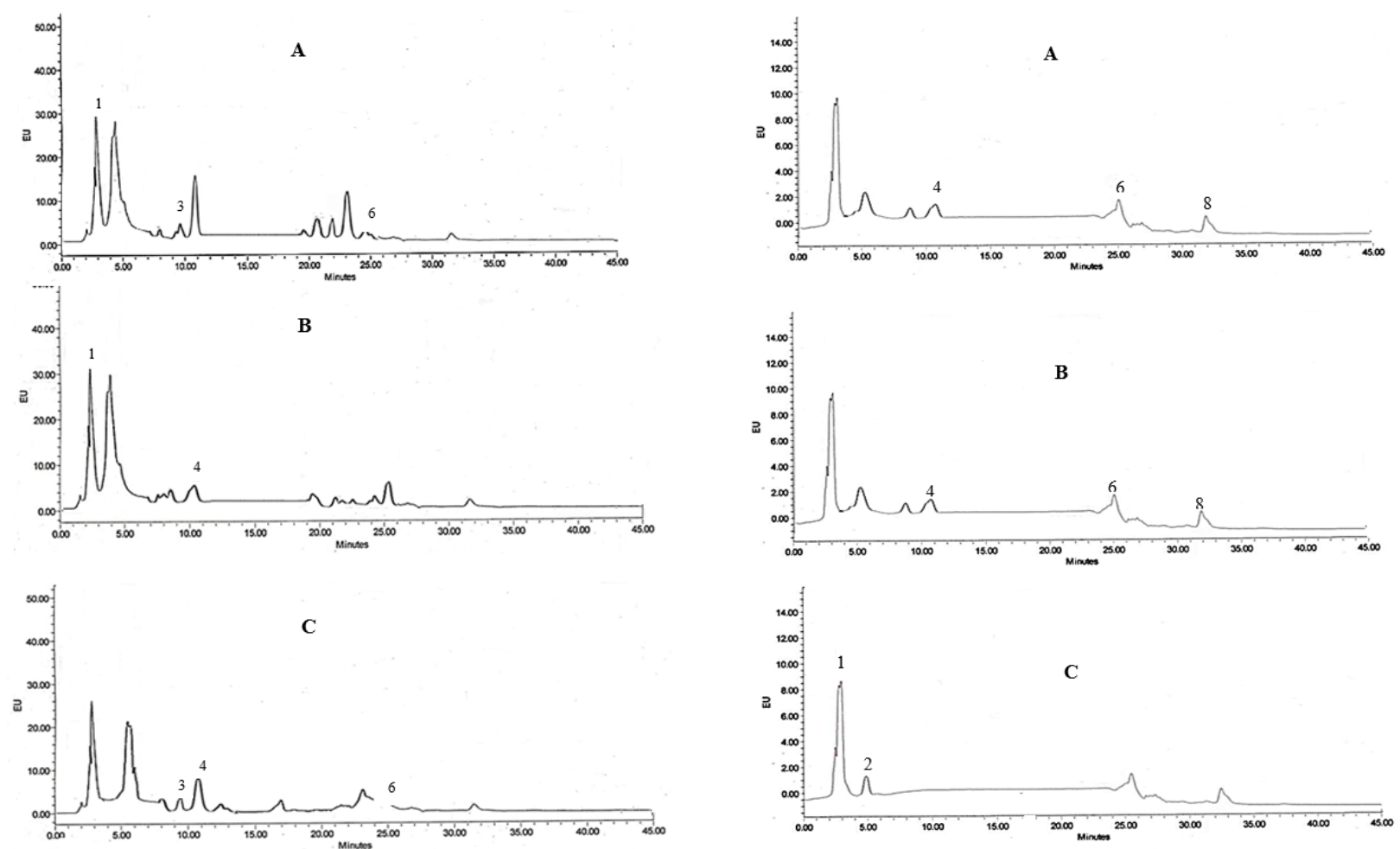

Figure 1. HPLC-profiles of phenolic compounds in Lentinus squarrosulus of three regions from central côte d'Ivoire

Figure 2. HPLC-profiles of phenolic compounds in Auricularia polirich of three regions from central côte d'Ivoire

A: L. squarrosulus Gbêkê, B: L. squarrosulus Bélier, C: L. squarrosulus N'zi) $\quad$ A: A. polytrich Gbêkê B: A. polytrich Bélier, C: A. polytrich N'zi Detection at $280 \mathrm{~nm}: 1$ (gallic acid: TR=2,8mn), 3 (protocatechiuc acid: TR= Detection at $280 \mathrm{~nm}: 1$ (gallic acid : TR=2,80 $\mathrm{mn}$ ), 2(Catechin: TR= 5min), 9,50mn), 4( $\rho$-Hydroxybenzoic acid: TR= 10,50mn), 6(ellagic acid: $\mathrm{TR}=25 \mathrm{mn}) \quad 4(\rho$-Hydroxybenzoic acid: TR=10,50mn), 6(ellagic acid: $T R=25 \mathrm{mn})$, $8($ naringenin: $\mathrm{TR}=32 \mathrm{mn})$

Table 2. Phenolic compounds contents (mg/kg DW) of samples L. squarrosulus and A. politrich of three regions from centre Côte d'Ivoire

\begin{tabular}{|c|c|c|c|c|}
\hline Phenolic compounds (mg/Kg) & Regions & $\begin{array}{l}\text { Retention Times } \\
(\mathrm{TR})(\mathrm{min})\end{array}$ & L. squarrosulus & A. politrich \\
\hline Gallic acid & $\begin{array}{l}\text { Gbêkê } \\
\text { Bélier } \\
\text { N'zi }\end{array}$ & 2.8 & $\begin{array}{c}100.85 \pm 0.07^{\mathrm{a}} \\
105.4 \pm 6.64^{\mathrm{b}} \\
\text { nd }\end{array}$ & $\begin{array}{c}\text { nd } \\
\text { nd } \\
105.70 \pm 6.50 \mathrm{a}\end{array}$ \\
\hline Catechin & $\begin{array}{l}\text { Gbêkê } \\
\text { Bélier } \\
\text { N'zi }\end{array}$ & 5 & $\begin{array}{l}\text { nd } \\
\text { nd } \\
\text { nd }\end{array}$ & $\begin{array}{c}\text { nd } \\
\text { nd } \\
28.50 \pm 2.12^{\mathrm{a}}\end{array}$ \\
\hline protocatechiuc acid & $\begin{array}{l}\text { Gbêkê } \\
\text { Bélier } \\
\text { N'zi }\end{array}$ & 9.5 & $\begin{array}{c}7.00 \pm 1.41^{\mathrm{b}} \\
\text { nd } \\
5.50 \pm 0.70^{\mathrm{a}} \\
\end{array}$ & $\begin{array}{l}\text { nd } \\
\text { nd } \\
\text { nd }\end{array}$ \\
\hline$\rho$-hydroxybenzoïc acid & $\begin{array}{l}\text { Gbêkê } \\
\text { Bélier } \\
\text { N'zi } \\
\end{array}$ & 10.5 & $\begin{array}{l}50.20 \pm 0.14^{\mathrm{c}} \\
25.50 \pm 2.12^{\mathrm{a}} \\
37.50 \pm 0.70^{\mathrm{b}}\end{array}$ & $\begin{array}{c}17.56 \pm 1.41^{\mathrm{a}} \\
20.20 \pm 0.14^{\mathrm{b}} \\
\text { nd }\end{array}$ \\
\hline$\rho$-coumaric acid & $\begin{array}{l}\text { Gbêkê } \\
\text { Bélier } \\
\text { N'zi }\end{array}$ & 13.5 & $\begin{array}{l}\text { nd } \\
\text { nd } \\
\text { nd }\end{array}$ & $\begin{array}{l}\text { nd } \\
\text { nd } \\
\text { nd }\end{array}$ \\
\hline Ellagic acid & $\begin{array}{l}\text { Gbêkê } \\
\text { Bélier } \\
\text { N'zi }\end{array}$ & 25 & $\begin{array}{c}\text { nd } \\
\text { nd } \\
14.00 \pm 1.41^{\mathrm{a}}\end{array}$ & $\begin{array}{c}27.34 \pm 0.14^{\mathrm{a}} \\
27.00 \pm 1.41^{\mathrm{a}} \\
\text { nd }\end{array}$ \\
\hline Naringenin & $\begin{array}{l}\text { Gbêkê } \\
\text { Bélier } \\
\text { N'zi }\end{array}$ & 32 & $\begin{array}{l}\text { nd } \\
\text { nd } \\
\text { nd }\end{array}$ & $\begin{array}{c}18.43 \pm 0.56^{\mathrm{a}} \\
18.50 \pm 0.70^{\mathrm{a}} \\
\text { nd }\end{array}$ \\
\hline
\end{tabular}

Means not sharing a similar letter in a line are significantly different $\mathrm{P}<0.05$ as assessed by the test of Duncan. nd: Not Detected, nd: no detected 


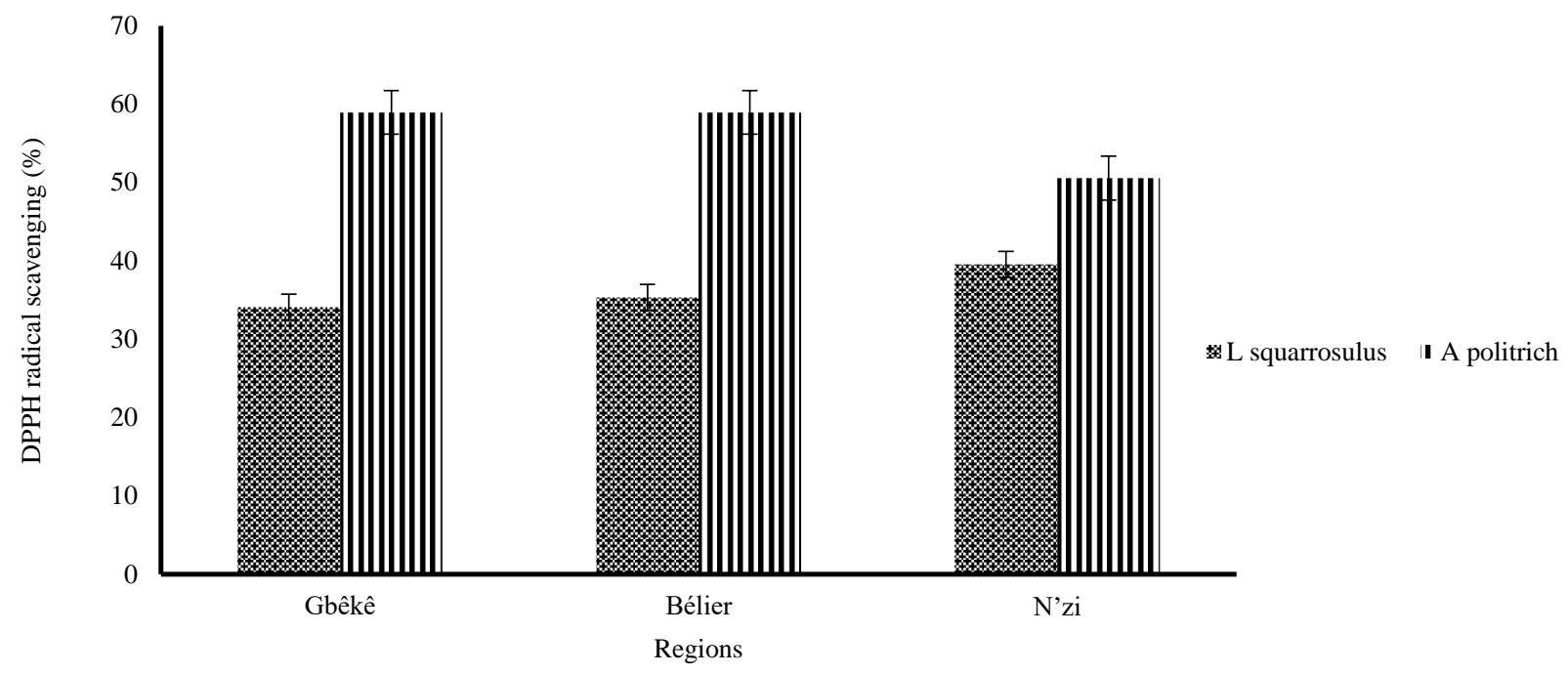

Figure 3: DPPH radical scavenging (\%) of extracts of samples of V.volvacea and P. tubercula from central Cote d'Ivoire
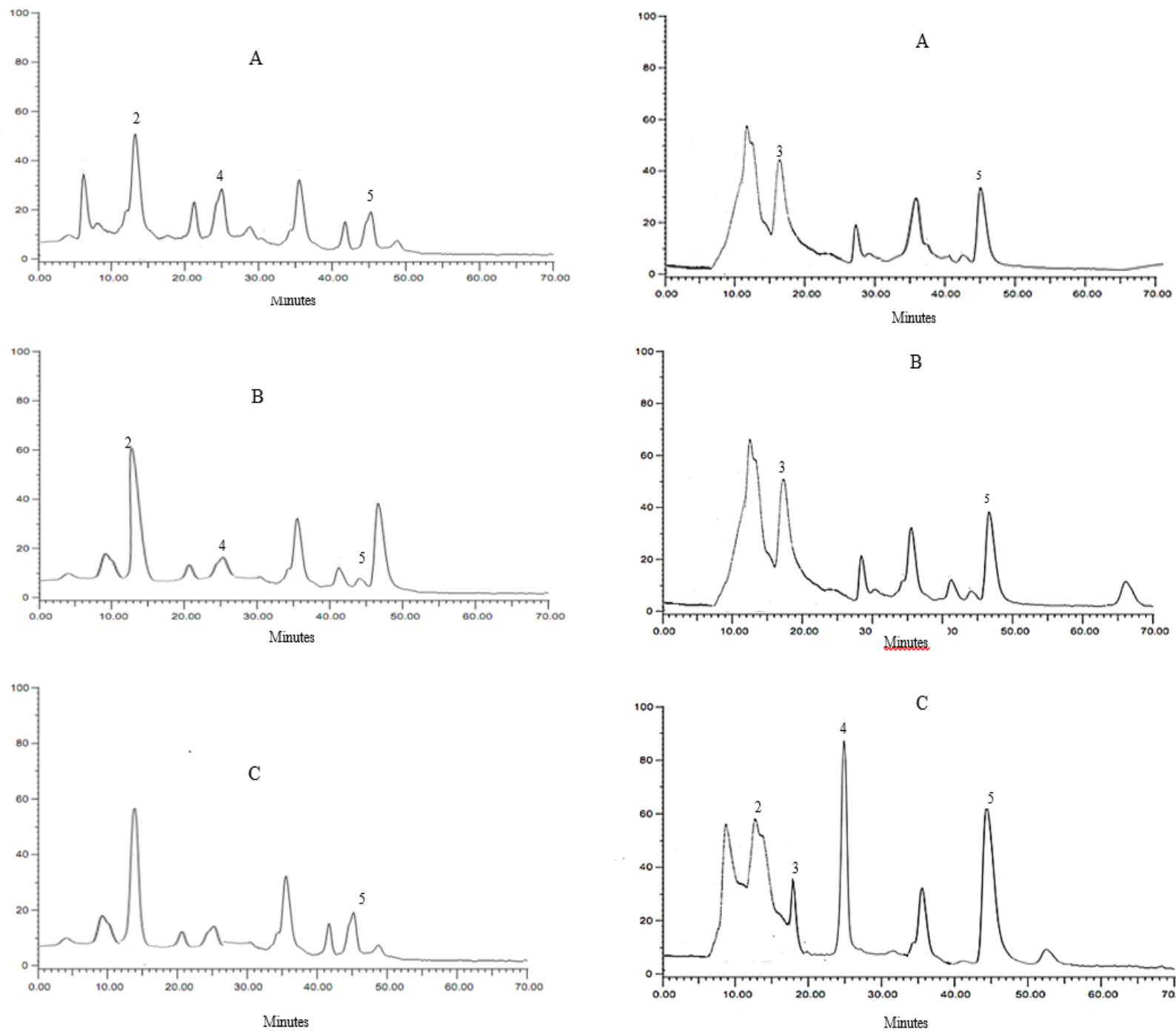

Figure 4. HPLC chromatograms of organic acids in Lentinus squarrosulus from center Côte d'Ivoire A: L. squarrosulus Gbêkê. B: L. squarrosulus Bélier. C: L. squarrosulus N'zi 2: citric acid $\mathrm{TR}=14 ; 4$ : shikimic acid $\mathrm{TR}=25 ; 5$ : fumaric acid $\mathrm{TR}=45$

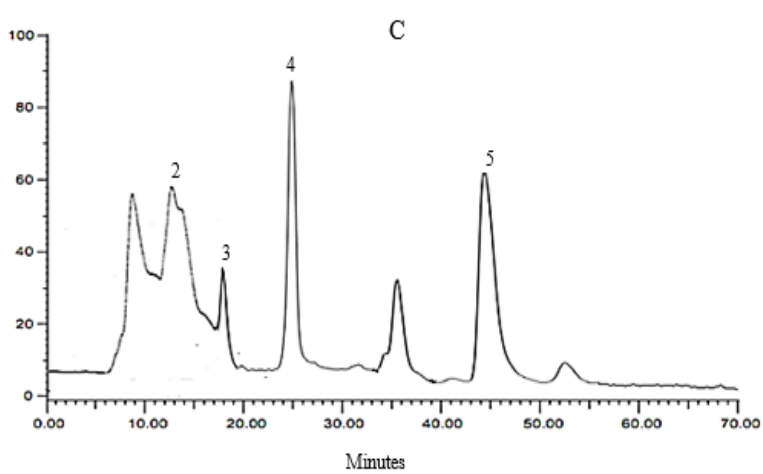

Figure 5. HPLC chromatograms of organic acids in Auricularia politrich from center Côte d'Ivoire 2: citric acid $\mathrm{TR}=14 ; 3$ : ascorbic acid $\mathrm{TR}=18$; 4: shikimic acid $\mathrm{TR}=25 ; 5$ : fumaric acid $\mathrm{TR}=45$ 


\section{Identification and Quantification of Organic Acids}

The organic acid profiles of Lentinus squarrosulus and Auricularia politrich showed that all the samples of the three administrative regions from center Côte d'Ivoire contained citric acid, shikimic acid, fumaric acid, ascorbic acid (Figure 4 and 5). The main organic acid found in samples of the three regions was fumaric acid. But citric acid was found in samples of Auricularia politrich in the three administrative regions (Table 3 ).

The profil in organic acid of the samples of Lentinus squarrosulus and Auricularia politrich showed that the citric acid and the fumaric acid are the majority compounds in these species. The contents in citric acid ranging from $1952.55 \pm 6.00$ to $2508.56 \pm 2.63$ and the one of the fumaric acid of $63.98 \pm 4.20$ to $2714.61 \pm 13.98$ whatever is the region (Table 3 ). Of these results one can deduct that the geographical origin have influenced the profile of organic acids of the mushrooms analysis as describes for the wild mushrooms dried of Portugal (Ribeiro et al., 2006).

The Bélier region record the strongest content in citric acid at the specie Lentinus squarrosulus. According to some authors, the citric acid is known to be very important in the prevention of mushroom browning and to extend its shelf life Due its antibacterial and antioxidant properties (Ribeiro et al., 2008; Kouassi et al., 2016). Auricularia politrich possesses the most elevated content fumaric acid in the region of N'zi. Fumaric acid is an important organic acid because of its antioxidant, antimicrobial and acidifying properties (Barros et al., 2013 ; Ribeiro et al., 2008).

Table 3. Contents (mg/kg DW) of organic acids of sample Lentinus squarrosulus and Auricularia politrich from center Côte d'Ivoire

\begin{tabular}{|c|c|c|c|c|}
\hline Organic acid (mg/Kg) & Regions & $\begin{array}{l}\text { Retentions times (TR) } \\
\text { (min) }\end{array}$ & L. squarrosulus & A. polytrich \\
\hline \multirow{3}{*}{ Citric acid } & Gbêkê & \multirow[t]{3}{*}{${ }^{2}$} & $2460.71 \pm 9.31^{\mathrm{a}}$ & nd \\
\hline & Bélier & & $2508.56 \pm 2.63^{b}$ & nd \\
\hline & N’zi & & nd & $1952.55 \pm 6.00^{\mathrm{a}}$ \\
\hline \multirow{3}{*}{ Ascorbic acid } & Gbêkê & \multirow{3}{*}{18} & nd & nd \\
\hline & Bélier & & nd & $396.49 \pm 7.71^{\mathrm{b}}$ \\
\hline & N'zi & & nd & $183.37 \pm 4.70^{\mathrm{a}}$ \\
\hline \multirow{3}{*}{ Shikimic acid } & Gbêkê & \multirow{3}{*}{25} & $285.73 \pm 4.70^{\mathrm{b}}$ & nd \\
\hline & Bélier & & $125.56 \pm 5.35^{\mathrm{a}}$ & nd \\
\hline & N'zi & & nd & $463.59 \pm 5.13^{\mathrm{a}}$ \\
\hline \multirow{3}{*}{ Fumaric acid } & Gbêkê & \multirow{3}{*}{45} & $227.43 \pm 4.20^{\mathrm{a}}$ & $63.98 \pm 4.20^{\mathrm{a}}$ \\
\hline & Bélier & & nd & nd \\
\hline & N'zi & & $262.52 \pm 7.09^{b}$ & $2714.61 \pm 13.98^{b}$ \\
\hline
\end{tabular}

Means not sharing a similar letter in a line are significantly different $\mathrm{P}<0.05$ as assessed by the test of Duncan. nd: Not Detected

\section{Conclusion}

According to the results of this study. mushroom species contains the phenolic compound, flavonoid, tanin and the antioxidant activities of samples of mushroom from center of Côte d'Ivoire. Total phenolic compound could make a significant contribution to the antioxidant activity in these sample. The mushroom species can be used as an easily accessible source of natural antioxidants and as a possible food supplement or in pharmaceutical industry. Consumption of dishes prepared from edible mushrooms is safe and beneficial due to good assimilability of their nutrients that are protective against civilization diseases and have vitalizing potential for human organism.

\section{Acknowledgement}

We are grateful to Dr Souleymane Yorou Nourou (Abomey Calavy University of Benin/ University of Munich. Tropical Mycology. Department Biology I. Organismic Biology. Germany) for advice and his contribution on taxonomic identification of the mushroom samples.

\section{References}

Aprotosoaie AC, Zavastin DE, Mihai CT, Voichita G, Gherghel D, Silion M, Trifan A, Miron A. 2017. Antioxidant and Antigenotoxic Potential of Ramaria Largentii Marr \& D. E. Stuntz, a Wild Edible Mushroom Collected from Northeast Romania. Food and Chemical Toxicology, 108 : 429-437.
Avit J-BLF, Pedia PL, Sankaré Y. (1999). Diversité biologique de la cote d'ivoire. Ministère de l'environnement et de la forêt. Abidjan : $276 \mathrm{p}$.

Barros L, Pereira C, Ferreira ICFR. 2013. Optimized analysis of organic acids in edible mushrooms from Portugal by UltraFast Liquid Chromatography and Photodiode Array Detection. Food Analytical Methods, 6: 309-316.

Barros L, Dueñas M, Ferreira ICFR, Baptista P, Santos-Buelga C. 2009. Phenolic acids determination by HPLC-DAD-ESI/MS in sixteen different Portuguese wild mushrooms species. Food Chemistry Toxicology, 47: 1076-1079.

Bainbridge Z, Tomlins K, Willings K, Westby A. 1996. Methods for assessing quality characteristics of non-grain starch staple. Part 4 advanced methods. National resources institute. University of Greenwich, UK ISBN 0-85954-400, p43-79.

Bidié AP, N'guessan BB, Yapo AF, N'guessan JD, Djaman AJ. 2011. Antioxidant activities of ten medicinal plants from the Ivorian pharmacopoeia. Sciences \& Nature, 8 (1): $1-11$.

Bożena M, Katarzyna SZ, Halina EJ. 2013. phenolic acids in selected edible basidio-mycota species: Armillaria mellea. Boletus badius. Boletus edulis. Cantharellus cibarius. Lactarius deliciosus and Pleurotus ostreatus Acta Sciences. Pol. Hortorum Cultus, 12 (4) : 107-116.

Erbiai EH, da Silva LP, Saidi R, Lamrani Z, Esteves da Silva JCG, Maouni A. 2021. Chemical Composition, Bioactive Compounds, and Antioxidant Activity of Two Wild Edible Mushrooms Armillaria mellea and Macrolepiota procera from Two Countries (Morocco and Portugal). Biomolecules, 11 (575) : 1-11. https:// doi.org/10.3390/biom11040575.

Ferreira ICFR, Barros L, Abreu RMV. 2009. Antioxidants in Wild Mushrooms. Current Medicinal Chemistry, 16: 1543-1560 
Ferreira ICFR, Baptista P, Vilas-Boas M, Barros L. 2007a. Freeradical scavenging capacity and reducing power of wild edible mushrooms from Northeast Portugal: Individual cap and stipe activity. Food Chemistry, 100: 1511-1516.

Ferreira I CFR, Baptista P, Vilas-Boas M, Barros L. 2007b. Freeradical scavenging capacity and reducing power of wild edible mushrooms from northeast Portugal: Individual cap and stipe activity. Food Chemistry, 100: 511-1516.

Hussein JM, Tibuhwa DD, Mshandete AM, Kivaisi A K. 2015. Antioxidant properties of seven wild edible mushrooms from Tanzania. African journal of food Science, 9 (9): 471-479.

Kouassi KA, Kouadio EJP, Konan KH, Due AE, Kouame LP. 2016a. Phenolic compounds, organic acid and antioxidant activity of Lactarius subsericatus, Cantharellus platyphyllus and Amanita rubescens, three edible ectomycorrhizal mushrooms from center of Cote d'Ivoire. Eurasian Journal of Analytical Chemistry, 11 (3): 127-139.

Kouassi KA, Kouadio EJP, Djè KM, Dué AE, Kouamé LP. 2016b. Edible Ectomycorrhizal Mushrooms Russula spp. of Côte d'Ivoire: Total Phenolic Content, HPLC-Profiles of Phenolic Compounds and Organic Acids, Antioxidant Activities. Journal of Agricultural Chemistry and Environment, 5: 73-84.

Ksouri R, Megdiche W, Falleh H, Trabelsi N, Boulaaba M, Smaoui A, Abdelly C. 2008. Influence of biological. environmental and technical factors on phenolic content and antioxidant activities of Tunisian halophytes. Critical. Research. Biology, 331: 865- 873.

Liaotrakoon W, Liaotrakoon V. 2018. Influence of drying process on total phenolics, antioxidative activity and selected physical properties of edible bolete (Phlebopus colossus (R. Heim) Singer) and changes during storage. Food Science and Technology, 38(2): 231-237.

Mau JL, Lin HC, Chen CC. 2002. Antioxidant properties of several médicinal mushrooms. Journal of Agricultural and Food Chemistry, 50: 6072-6077.

Meda A, Lamien CE, Romito M, Millogo J, Nacoulma OG. (2005). Determination of the total phenolic. flavonoid and proline contents in Burkina Fasan honey as well as their radical scavenging activity. Food Chemistry, 91: 571-577.

Middleton E, Kandaswami C, Theoharides TC. 2000. The effects of plant flavonoids on mammalian cells: implications for inflammation. heart disease and cancer. Pharmacologie Reviews, 52: 673-839.

Mizuno T, Wang G, Zhang J, Kawagishi H, Nishitoba T, Li J. 1995. Reishi. Ganoderma lucidum and Ganoderma Tsugae: bioactive substances and médicinal effects. Dans: Mizuno. T. (éd.). Spécial Issue on Mushrooms: The Versatile Fungus Food ad Médicinal Properties. Chemistry Biochemistry Biotechnology and Utilization. Food Reviews International, 11: 151-166.

Muszyńska B, Sułkowska-Ziaja K, Ekiert H. 2013. Phenolic acids in selected edible basidiomycota species, Armillaria mellea, Boletus badius, Boletus edulis, Cantharellus cibarius, Lactarius deliciosus and Pleurotus ostreatus. Acta Scientiarum Polonorum Hortorum Cultus, 12 (4): 107-116.

Obodai M, Apetorgbor M. 2014. "An Ethnobotanical Stu- dy of Mushroom Germplasm and Its Domestication in the Bia Biosphere Reserve of Ghana," Report Presented to UNESCO through Environmental Protection Agency of Ghana, Accra $66 \mathrm{p}$.

Puttaraju NG, Venkateshaiah SU, Dharmesh SM, Somasundaram R. 2006. Antioxidant activity of indigenous edible mushrooms. Journal of Agricultural and Food Chemistry, 54: 9764-9772.
Ribeiro B, Andrade PB, Baptista P, Barros L, Ferreira ICFR, Seabra RM, Valentao P. 2008. Leucopaxillus giganteus mycelium: Effect of nitrogen source on organic acids and alkaloids. Journal of Agricultural and Food Chemistry, 56: 4769-4774.

Ribeiro B, Valentão P, Baptista P, Seabra RM, Andrade PB. 2007. Phenolic compounds, organic acids profiles and antioxidative properties of beefsteak fungus (Fistulina hepatica). Food and Chemical Toxicology, 45: 1805-1813.

Ribeiro B, Valentao P, Baptista P, Seabra RM, Andrade PB. 2006. Phenolic compounds, organic acids profiles and antioxidative properties of beefsteak fungus (Fistulina hepatica). Food Chemical Toxicology, 45: 1805-1813.

Siangu BN, Sauda S, John MK, Njue WM. 2019. Antioxidant activity, total phenolic and flavonoid content of selected Kenyan medicinal plants, sea algae and medicinal wild mushrooms. African Journal of Pure and Applied Chemistry, 13(3) : 43-48.

Silva BM, Andrade PB, Valenta o P, Ferreres F, Seabra RM, Ferreira MA. 2004. Quince (Cydonia oblonga Miller) fruit (pulp. peel. and seed) and jam: antioxidant activity. Journal of Agricultural and Food Chemistry, 52. 4705-4712

Singleton V L, Orthofer R, Lamuela-Raventos R M. 1999. Analysis of total phenols and other oxidation substrates and antioxidants by means of Folin-Ciocalteu reagent. Methods in Enzymology, 299: 152-178.

Stanton JL. 2006. Annual report on the bi-monthly mushroom tracking

report:http://www.mushroomcouncil.org/docs/2006_01+An nual+tracking+Report+.pdf.(05/07/14)

Tibuhwa DD, Mwanga ZN. 2014. A comprehensive study on Agaricus-like mushrooms from Mwalimu JK Nyerere Mlimani Campus. Tanzania Journal of Biology, Agriculture and Healthcare, 4 (21): 70-78.

Tripathy SS, Rajoriya A, Gupta N. 2014. Wild Mushrooms of Odisha, Prospective Candidates of Antioxidant Sources. Advance in Plants \& Agriculture Research, 1(4):129-133. DOI: 10.15406/apar.2014.01.00021

Valentão P, Lopes G, Valente M, Barbosa P, Andrade PB, 2005. Quantitation of Nine Organic Acids in Wild Mushrooms. Journal Agriculture Food Chemistry, 53: 3626-3630.

Vieira Gomes DC, Barros M VO, dos Reis AC, Rosália Maria Torres RM, Victor J, Ferreira AMO, Soares Dias AC, Da Costa JSJ, Das Graças MF, Jardim Paz MFC, Gayoso LC, João Marcelo J, Islam MT, Melo Cavalcante A A. 2019. Antioxidant, anti-inflammatory and cytotoxic/antitumoral bioactives from the phylum Basidiomycota and their possible mechanisms of action. Biomedicine \& Pharmacotherapy 112 $: 1-8$.

Wills RM, Lipsey RG. 1999. An economie strategy to develop non-timber forest products and services in British Columbia: Forest Renewal BC Project No. PA97538-ORE: http://www.sfu.ca/ rlipsey/FRBC.PDF.

Wong FC, Chai TT, Tan SL, Yong AL. 2013. Evaluation of Bioactivities and Phenolic Content of Selected Edible Mushrooms in Malaysia Tropical. Journal Pharmaceutical Research, 12(6): 1011-1016.

Yuwa-Amornpitak T, Butkhup L, Yeunyaw PN. 2020. Amino acids and antioxidant activities of extracts from wild edible mushrooms from a community forest in the Nasrinual District, Maha Sarakham, Thailand. Food Science and Technology, 40(3): 712-720. 